\title{
Peranan Guru Pendidikan Agama Islam dalam Menanggulangi Kenakalan Siswa
}

\author{
Nurul Hasikin' ${ }^{1}$ Rahmi Wiza ${ }^{2}$ \\ nurulhasikin698@gmail.com¹, rahmiwiza@fis.unp.ac.id² \\ Universitas Negeri Padang1,2
}

\begin{tabular}{l}
\hline ARTICLE INF0 \\
\hline Article history: \\
Received, 21 Oktober 2021 \\
Revised, 26 Februari 2021 \\
Accepted, 28 Februari \\
2022 \\
\hline
\end{tabular}

Keywords:

Peranan Guru Pendidikan

Agama Islam, Kenakalan

Siswa.

\section{Conflict of Interest:}

None

Funding:

None

\begin{abstract}
This research is motivated by the community's view of the school which was initially famous for naughty children, then over time, this school has increasingly experienced an increase in a better direction. This study aims to determine the causes of student delinquency and the role of Islamic Religious Education teachers in tackling student delinquency. This type of research is qualitative with the case study method. (Nazir, 2003) said this case study research aims to study and understand a specific case, wherein the early stages of research it is equipped with a theoretical framework with the analysis in the form of one person, one organization, or a case and the researcher acts as an observer who analyzes why and how. of a case. Data collection techniques using interviews, observation, and documentation. The data that has been collected is then analyzed by data reduction, data presentation, and drawing conclusions. The validation of the data in this study used source triangulation, in which the researcher compared several informants in order to obtain valid data. The results showed that student delinquency that occurred at SMPN 9 Payakumbuh City was still classified as moderate delinquency, such as smoking, skipping school without explanation, fighting, saying rude and being disrespectful to the teacher.
\end{abstract}

Corresponding Author: Nurul Hasikin, Department Islamic Education Faculty of Social Science Universitas Negeri Padang, Indonesia, Email: nurulhasikin698@gmail.com, Phone No.: +6282211152840

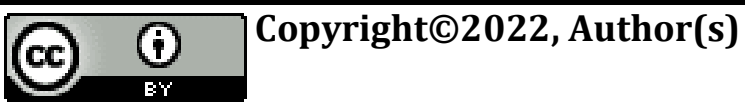

\section{Pendahuluan}

Dalam bahasa Arab pengertian pendidikan, sering digunakan beberapa istilah antara lain, al-ta'lim, al-tarbiyah, dan al-ta'dib. al-ta'lim berarti pengajaran yang bersifat pemberian atau penyampaian pengetahuan dan keterampilan, al-tarbiyah berarti mengasuh mendidik, al-ta'lib lebih cenderung kepada proses pendidikan yang bertujuan pada penyempurnaan akhlak dan moral peserta didik. Namun kata pendidikan ini lebih sering diterjemahkan dengan kata "tarbiyah" yang berarti 
Nurul Hasikin dan Rahmi Wiza: Peranan Guru Pendidikan Agama Islam dalam...

pendidikan. Pendidikan Islam adalah bimbingan jasmani, rohani berdasarkan hukumhukum agama Islam. (Azis, 2019)

Guru sebagai pelaku utama dalam penerapan program pendidikan di sekolah memiliki peran yang sangat penting untuk mencapai tujuan pendidikan. Peran guru yaitu sebagai pendidik, pembimbing, melatih, menasehati, melakukan pembaruan, menjadi contoh dan teladan, memiliki kepribadian yang baik, peneliti, mendorong kreatifitas, membangkitkan pandangan, melakukan pekerja rutin, membawa cerita, menjadi aktor, emansipator, mengawetkan dan melakukan evaluasi. Peran guru dalam perkembangan pendidikan meliputi: penanaman nilai, membangun karakter, sentral pembalajaran, memberi bantuan dan dorongan, melakukan pengawasan dan pembinaan, mendisiplinkan anak dan panutan bagi lingkungan (Juhji, 2016)

Meskipun demikian masih terdapat beberapa kenakalan di dunia pendidikan yang mana menurut ilmuwan sosiologi "Kartono" mengatakan kenakalan siswa merupakan gejala patologis sosial pada siswa yang disebabkan oleh satu bentuk pengabaian sosial dan akibatnya mereka membentuk perilaku meyimpang. Adapun menurut "Santrock" kenakalan siswa merupakan kumpulan dari berbagai perilaku siswa yang tidak dapat diterima secara sosial hingga berujung pada tindakan kriminal.

Penyebab terjadinya kenakalan siswa adalah berawal dari perilaku "nakal" yang ada pada siswa disebabkan oleh beberapa faktor yaitu faktor internal adalah kenakalan yang datang dari dalam diri siswa itu sendiri, dikarenakan tidak adanya rasa ingin dari diri siswa untuk beradaptasi dengan lingkungan sehingga menimbulkan perilaku yang menyimpang. Kemudian juga terjadi karna faktor eksternal atau dari luar diri siswa tersebut seperti lingkungan dalam keluarga, sekolah dan masyarakat. Faktor tersebutlah yang menimbulkan pengaruh sangat besar dalam membentuk kepribadian dan sikap siswa. Lingkungan yang baik akan membentuk perilaku menjadi baik, begitupun sebaliknya (Prasasti, 2017)

Berdasarkan observasi awal yang peneliti lakukan pada tanggal 20 Februari 2021 bahwa di kota Payakumbuh terdapat sepuluh SMP Negeri, diantaranya ada satu SMP yang di kenal dengan anak-anak yang nakal, yaitu SMPN 9 Kota Payakumbuh siswa di sekolah ini sering melakukan pelanggaran seperti bolos, tidak patuh kepada guru, sering berkelahi dan menghisap lem. Hal ini terbukti pada maret 2014 terjadi aksi tawuran dengan sekolah lain yang menggunakan senjata tajam dan siswa sekolah ini sempat diamankan di POLRES Kota Payakumbuh (Wawancara dengan kepala sekolah 23 Mei 2021).

Namun dari tahun 2014-2020 SMP ini semakin mengalami peningkatan dan perbaikan dari sistem sekolah, terbukti dari banyaknya prestasi yang telah diraihnya. sekolah ini memiliki prestasi yang unggul dalam bidang olahraga salah satunya sepak bola. Pada tahun 2017 sekolah ini meraih juara LPI, kemudian beberapa siswanya lolos masuk liga Semen Padang. Seiring meningkatnya prestasi siswa perilaku siswapun telah banyak mengalami perubahan kearah yang lebih baik.

\section{Tinjauan Pustaka}

Guru disebut guru pendidikan agama Islam karena tugas utamanya terletak pada kemampuan membelajarkan bagaimana agama Islam bisa dipahami dan dilaksanakan oleh pesrta didik secara tepat dan poporsional. Proses mengetahui, memahami dan mengaplikasikan tidak semudah membalik telapak tangan. Perlu proses yang matang, lama, kontinu atau sistemastis (Muchith, 2016). 
Peranan menurut (Roji \& Asiyak, 2021) adalah aspek dinamis dari kedudukan (status). Apabila seseorang melaksanakan hak dan kewajibannya, maka dia menjalankan suau peran. Keduanya tidak dapat dipisahkan karena satu dengan yang lain saling tergantung, artinya tidak ada peran tanpa status dan tidak ada status tanpa peran. Maka setiap orang dapat mempunyai macam-macam peran yang berasal dari pola pergaulan hidupnya.

Secara umum tugas utama guru adalah mengajar, membimbing, mengarahkan, melatih, menilai, mengevaluasi peserta didik dan mendidik murid di kelas dan di luar kelas. Guru selalu berhadapan dengan murid yang memerlukan pengetahuan, keterampilan dan sikap utama untuk menghadapi hidupnya di masa depan. Pendidik dalam perspektik Islam ialah orang yang bertanggungjawab terhdap upaya perkembangan jasmani dan rohani peserta didik (Ismail, 2017).

Guru dituntut memiliki kompetensi yang unggul dibidangnya, kompetensi pedagogik guru merupakan salah satu kompetensi yang harus dimiliki setiap guru dalam jenjang pendidikan dan bidang apapun, tak terkecuali guru pendidikan agama Islam. Bila guru pendidikan agama Islam tidak dapat meningkatkan kompetensi pedagogiknya, maka akan berpengaruh pada siswa menerima transformasi pengetahuan dalam proses pembelajaran, sehingga pembelajaran dianggap gagal dan pendidikan menjadi hal yang tabu dan tidak penting dalam pandangan masyarakat (Hambali, 2016)

Kenakalan siswa adalah kenakalan yang dilakukan anak-anak muda, yang merupakan gejala sakit (potologis) yang disebabkan oleh satu bentuk pengabaian sosial, sehingga mereka mengembangkan bentuk tingkah laku yang menyimpang. Juvenile berasal dari bahasa latin "jurvenilis, artinya anak-anak, anak muda. Delinquent berasal dari Bahasa latin yaitu "delinquere", yang berarti terabaikan, yang kemudian diperluas menjadi jahat, anti sosial, kriminal, pelanggaran aturan, pembuat onar, pengacau dan lain-lain. (Unayah, 2016)

Kenakalan siswa sangat marak sekali saat ini dan dari tahun ke tahun itu mengalami peningkatan baik itu dikota besar maupun kota kecil, bentuk kenakalan remaja itu beragam. Menurut (Mulyanti, 2013) belakangan ini siswa yang menyimpang makin mencemaskan masyarakat. Mereka tidak lagi sekedar terlibat dalam kenakalan ringan seperti membolos sekolah, merokok, minum-minuman keras, atau menggoda lawan jenis, tetapi tak jarang mereka terlibat dalam kasus kriminalitas seperti penjambretan, terlibat dalam aksi tawuran layaknya preman, pemerasan, pencurian, perampokan, penganiayaan, memakai obat-obatan terlarang, bahkan terjerumus dalam kehidupan seksual diluar nikah dan masih banyak bentukbentuk kenakalan lainnya.

Kenakalan siswa itu sendiri disebabkan oleh beberapa faktor-faktor yang pertama faktor internal, hal ini disebabkan karena siswa msih dalam proses pencarian jati dirinya, sehingga belum terlalu bisa membedakan mana yang baik dan buruk. Kedua faktor external, hal ini bisa datang dari keluarga, lingkungan masyarakat, pengaruh teman sebaya, pengaruh media sosial dan sebagainya ( (Suci, 2017).

\section{Metode}

Jenis penelitian ini adalah penelitian kualitatif dengan menggunakan metode studi kasus. Penelitian kualitatif adalah jenis penelitian yang digunakan jika masalah yang 
Nurul Hasikin dan Rahmi Wiza: Peranan Guru Pendidikan Agama Islam dalam...

dihadapi belum jelas, mengetahui makna yang tersembunyi, memahami interaksi sosial, mengembangkan teori, memastikan kebenaran data, serta untuk meneliti sejarah perkembangan (Mamik, 2015). Sedangkan (Nazir, 2003) mengatakan penelitian studi kasus ini bertujuan mempelajari dan memahami sebuah kasus yang spesifik, dimana pada tahapan awal penelitian sudah dibekali kerangka teori dengan analisisnya berupa satu orang, satu organisasi, atau suatu kasus dan peneliti berperan sebagai pengamat yang menganalisis why dan how dari suatu kasus.

Sumber data penelitian yang penulis ambil ialah sembilan informan melalui wawancara langsung, yang mana informan tersebut terdiri dari satu orang kepala sekolah, dua orang guru pendidikan agama Islam, satu orang guru bimbingan dan konseling, tiga orang siswa yang awalnya nakal menjadi siswa berprestasi dan dua orang siswa nakal di SMP N 9 Kota Payakumbuh. Untuk memperkuat data penelitian, penulis juga mengambil data melalui observasi kepada lingkungan sekolah dan pada sarana prasarana sekolah. Selanjutnya sebagai bukti penulis menjalankan penelitian terkait isu dan permasalahan yang dikaji, maka penulis juga mengabadikan seluruh kegiatan yang dilakukan seperti wawancara langsung dengan seluruh informan, dan kondisi lingkungan sekolah serta sarana dan prasarananya.

Data wawancara penulis dengan informan dianalisis dengan cara model analisis Miles Huberman, ananlisis data menurut Miles dan Huberman dimulai dari pengumpulan data data, reduksi data, penyajian data, dan diakhiri dengan pengambilan kesimpulan. Cara yang digunakan peneliti dalam menguji keabsahan data yaitu menggunakan triangulasi. Triangulasi merupakan sebuah cara mengkaji keabsahan data dengan memanfaatkan berbagai sumber, berbagai waktu dari data yang telah dikumpulkan. (Sugiyono, 2020)

\section{Hasil dan Pembahasan}

Faktor Penyebab Terjadinya Kenakalan Siswa di SMPN 9 Kota Payakumbuh

Pada masa sekarang ini banyak sekali terjadi pelanggaran-pelangaran yang dilakukan oleh siswa, mulai dari kenakalan yang ringan, sedang sampai kenakalan yang berat. kenakalan yang dilakukan siswa ini tidak hanya menjadi tanggung jawab bagi dirinya sendiri, tetapi juga menjadi tanggung jawab bagi orang-orang disekitarnya. Penyebab dari kenakalan siswa ini dikarenakan beberapa faktor yaitu dari dalam diri siswa itu sendiri, keluarga, sekolah dan lingkungan masyarakat. Berdasarkan hasil penelitian yang didapatkan peneliti melalui observasi dan wawancara dengan beberapa informan maka didaptkan ada beberapa faktor yang mempengaruhi kenakalan siswa di antaranya.

Pertama, pencarian jati diri. remaja yang sedang mencari jati dirinya akan memcoba semua hal yang belum pernah mereka lakukan sebelumnya, karena masa remaja ini adalah masa transisi yang mana siswa sebagai remaja awal seringkali mengalami ketidakstabilan dalam mengontrol emosi. Hal ini sesuai dengan wawancara peneliti bersama ibu husni beliau mengatakan bahwa: "Penyebab siswa yang bermasalah memang salah satu faktornya disebabkan oleh tidak mampunya seorang siswa tersebut dalam mengontrol emosi sehingga terjadi perilaku menyimpang".

Hal ini senada dengan yang diungkapkan Ragil siswa kelas IX dia menyampaikan bahwa: "Saya merupakan anak ke tiga dari tiga bersaudara, saya memiliki kakak perempuan dan kakak laki-laki, kedua orang tua saya masih utuh, saya mendapat kasih 
sayang dan perhatian penuh dari keluarga, penyebab berkelahi karena terpancing emosi oleh teman saya"

Kedua, lingkungan keluarga. Keluarga merupakan lembaga utama pendidikan dan sangat berperan penting dalam mmbentuk karakter siswa, tapi tidak semua siswa memiliki keluarga yang utuh dan harmonis, keluarga yang tidak utuh dan kurang harmonis ini seringkali membuat anak kurang mendapatkan kasih sayang sehingga mereka mencari hal itu diluar sana yang menyebabkan anak menjadi salah pergaulan dan membangkang.

Hal ini sebagaimana yang disampaikan oleh ibu resa, beliau mengatakan:

"Siswa yang sering ibu temui dan ibu beri nasihat, memang faktor utama siswa nakal itu adalah keluarga, tidak semua anak memiliki orang tua yang lengkap dan harmonis, ada juga yang orang tuanya sibuk sehingga tidak memperhatikan anak hal ini menyebabkan anak kurang mendapat perhatian dan akhirnya mencari perhatian diluar".

Hal ini juga dirasakan oleh ibu Husni, beliau mengatakan:

"Sebenarnya anak nakal di SMPN 9 ini di pengaruhi oleh keadaanya, keluarga, ada beberapa siswa yang memiliki latar belakang keluarga yang kurang harmonis dan ada juga yang tidak memiliki orang tua sama sekali". Dan hal ini sejalan dengan apa yang dikatakan oleh Teguh Prananda siswa Kelas IX melalui wawancara pada tanggal 10 agustus 2021 dia mengatakan: "Orang tua saya sudah bercerai, ibu bekerja di Malaysia dan saya tinggal dengan nenek. pelaggaran yang sering saya lakukan berkelahi, membolos dan tidak membuat tugas".

Ketiga, lingkungan sekolah. Sekolah juga bisa menjadi salah satu faktor anak berkelakuan nakal, karena selain menjadi tempat untuk menuntut ilmu sekolah juga menjadi tempat bersosialisasi bagi siswa baik itu dengan guru, teman sebaya dan seluruh warga disekolah. Namun terkadang lingkungan sekolah juga dapat menjadi ancaman bagi siswa unuk berkelakuan nakal.

Hal ini sesuai dengan yang dikatakan oleh ibu resa melalui wawancara dengan beliau, dia mengatakan: "Lingkungan sekolah juga bisa menyebabkan siswa berkelakuan nakal, karena ada sebagian guru yang sering menasehati siswa didepan orang ramai. ini akan sangat merusak mental siswa dan menjadikan siswa itu membangkang".

Keempat, lingkungan Masyarakat. Selain faktor keluarga ternyata faktor lingkungan ini juga sangat berpengaruh untuk anak menjadi nakal, karena siswa setelah sekolah kebanyakan menghabiskan waktu bermain dengan teman dilingkungan tempat tinggalnya. Jika lingkungan masyarakat si anak tidak baik maka besar kemungkinan untuk anak akan terjerumus dalam perilaku menyimpang. Sebagaimana yang dismpaikan ibu husni selaku guru bimbingan dan konseling, beliau mengatakan:

"Kalau kenakalan di SMPN 9 ini yang ibu lihat salah satu faktornya adalah lingkungan masyarakat". Hal ini Sesuai dengan hasil wawancara peneliti dengan ibu resa beliau mrengatakan: "Siswa yang berkelakuan nakal ini kebanyakan bertempat tinggal di daerah pasar yang mana lingkungan disana kurang sehat, disana banyak anak-anak yang putus sekolah akhirnya menjadi anak jalanan yang tidak terurus dan ini sangat berpengaruh untuk siswa yang berada dilingkungan seperti itu menjadi ikut menyimpang". 
Nurul Hasikin dan Rahmi Wiza: Peranan Guru Pendidikan Agama Islam dalam...

\section{Peranan Guru Pendidikan Agama Islam dalam Menanggulangi Kenakalan Siswa di SMPN 9 Kota Payakumbuh.}

Peranan guru PAI bukan hanya sebagai pengajar karena mengajar sudah menjadi kewajiban bagi setiap guru, seorang guru memiliki peranan yang multifungsi yaitu: guru PAI sebagai motivator, guru harus mampu memotivasi siswa agar selalu berperilaku positife, guru sebagai orang tua siswa di sekolah, seorang guru haruslah menyayangi siswa seperti anak sendiri dan tidak boleh membedakan antara siswa yang satu dengan yang lain, pemberi infromasi yang akurat, disini seorang guru menjadi penyampai suatu informasi yang dibutuhkan oleh siswa. guru juga harus menjadi suri tauladan yang mana setiap langkah yang diambilnya akan dicontoh oleh siswa nantinya. Sebagaimana yang dikatakan oleh ibu sofi melalui wawancara yang peneliti lakukan, beliau mengatakan: "Selain sebagai pendidik guru PAI juga berperan dalam menanggulangi kenakalan, melalui pendekatan kepada siswa dan juga guru PAI bekerjasama dengan wali kelas, guru BK, wakil kesiswaan dan kepala sekolah dengan harapan dapat merubah akhlak siswa".

Sejalan dengan hal ini kepala sekolah juga berpendapat tentang pentingnya peran guru PAI melalui wawancara pada tanggal 2 Agustus 2021 beliau mengatakan: "Kedua guru PAI di sini ibu tuntut untuk membuat program baik untuk mata pelajaran yang berkaitan dengan agama maupun dengan program ekstrakurikulernya. Kemudian guru PAI dan ibu membuat kegiatan ekstrakurikuler berupa kegiatan forum annisa, forum arijjal, hafiz al qur'an, kegiatan BTQ (baca tulis qur'an) dan kegiatan muhadharah pada hari Jumat. Peranan guru PAI ibu lihat sangat penting dan sangat berpengaruh, tanpa adanya guru PAI dalam pembelajaran agama ini kalua digantikan oleh guru lain mungkin bisa jadi salah arah."

\section{Faktor Pendukung dan Faktor Penghambat guru PAI dalam Menanggulangi kenakalan Siswa di SMPN 9 Kota Payakumbuh}

Pertama, faktor pendukung. Berdasarkan wawancara penulis pada tanggal $30 \mathrm{Juli}$ 2021 dengan ibu Resa selaku guru PAI beliau mengatakan faktor pendukung dalam menanggulangi kenakalan siswa adalah: Kerjasama yang baik antara orang tua siswa dan guru, baik dengan wali kelas, guru BK, kepala sekolah dan guru agama itu sendiri. Sejalan dengan hal ini kepala sekolah juga menyampaikan dalam wawancara pada tanggal 2 Agustus 2021 beliau mengatakan:

"Selama ini Alhamdulillah tidak ada gangguan yang kami rasakan, karena berhubung sekolah ini terletak disebelah kantor polisi sendiri, kemudian juga sekolah ini letaknya strategis yaitu berada dijalan lintas dan ibu juga ketat aturannya untuk penjaga sekolah, kalua dia tidak ada ditempat ibu minta untuk mencari penggantinya. Alhamdulillah untuk fasilitas dan sarana prasarananya bagi kami sudah mencukupi tapi masih banyakyang ingin ditambah lagi. Kemudian untuk lapangan bermain basket kita ada, perpustakaan sudah cukup bagus ibu rasa, labor TIK kami juga komputernya banyak bahkan berlebih".

Kedua, faktor penghambat. Selain ada faktor pendukung juga ada faktor penghambat guru PAI dalam menanggulangi kenakalan siswa sebagaimana yang dikatakan oleh ibu Resa Permana Sari melalui wawancara pada tanggal 30 Juli 2021 yaitu: "faktor penghambat bagi ibu dalam menanggulangi kenakalan siswa di SMPN 9 ini adalah saran dari guru lain untuk tidak terlalu dekat dengan siswa, hal ini membuat 
ibu susah untuk memasuki kehidupan siswa itu sendiri. Karena pendekatan dengan siswa ini berbeda harus pelan-pelan, dengan menjadi teman untuk anak tersebut ibu fikir itu sangat efektif untuk mengetahui permasalahan dan mengedukasi siswa tersebut".

\section{Simpulan}

Guru PAI menyampaikan ilmu serta membentuk kepribadian dan akhlak siswa. selain berperan sebagai pengajar dan orang tua siswa disekolah, guru juga memotivasi siswa melalui kegiatan kegaman yang diadakakan disekolah, seperti perayaan hari besar islam, forum annisa, forum arijjal, BTQ, Hafiz qur'an dan muhadarah. Faktor pendorong siswa berkelakuan nakal adalah pengaruh teman sebaya yang mengajak kepada penyimpangan, lingkungan masyarakatnya yang tidak sehat, serta tidak ada dukungan dari orang tua dan juga guru yang sering memarahi siswa di depan orang ramai. Faktor penghambat guru PAI dalam menanggulangi kenakalan siswa adalah kurangnya dukungan dari beberapa guru, orang tua siswa dan lingkungan masyarakat, karena kebanyakan siswa yang berkelakuan nakal ini memang bertempat tinggal di daerah pasar, yang mana lingkungan ini cukup keras dan kurang sehat untuk perkembangan siswa, yang menyebabkan siswa yang tinggal disana terpengaruh oleh teman-temannya yang putus sekolah.

\section{Referensi}

Abdurrahman, F. (2011). Metodologi Penelitian dan Teknik Penyusunan Skripsi. Jakarta: Rineka Cipta.

Ahmad, T. (2005). Ilmu Pendidikan dalam Perspektif Islam . Bandung: Remaja Rosda Karya.

Cicih, S. (2012). Etika Profesi. Jakarta: Direktor Jendral Pendidikan Islam, Kementrian Agama RI.

Dakir, \& Sardimi. (2011). Pendidikan Islam\& ESQ: Komparasi- Integratif Upaya Menuju Stadium Insan Kamil. Semarang: Rasail Media Grup.

Djamaluddin, A. (2014). Filsafat Pendidikan. Istiqra : Jurnal Pendidikan dan Pemikiran Islam , 1(2).

Faidatul, L. (2020). (Doctoral dissertation, Universitas Muhammadiyah Jember). Peran Guru PAI dalam membentuk Karakter Siswa di MTs Miftahul Ulum Panti.

Fuadah, N. (2011). Gambaran Kenakalan Siswa di SMA Muhammadiyah 4 Kendal. Jurnal Psikologi Esa Unggul.

Hidayat, R. (2015). (Doctoral dissertation, IAIN). UPAYA GURU PENDIDIKAN AGAMA ISLAM DALAM MENANGGULANGI KENAKALAN SISWA DI SMP MUHAMMADIYAH SUMBANG.

Juhji, J. (2016). Peran Urgen Guru dalam Pendidikan. Studia Didaktika, 
Nurul Hasikin dan Rahmi Wiza: Peranan Guru Pendidikan Agama Islam dalam...

51-62. Kamus Besar Bahasa Indonesia. (2007). (Jakarta : Balai Pustaka). 845.

Kartini, K. (1998). Kenakalan Remaja. Jakarta: PT Raja Grafindo,

Persada. Mamik. (2015). Metode Kualitatif. Sidoarjo: Zifatma

Publisher .

Moleong , L. (2017). Metode Penelitian Kualitatif. Bandung: PT Remaja Rosdakarya Offset.

Muhibbin, S. (2009). Psikologi Pendidikan Dengan Pendekatan Baru. Bandung: Remaja Rosda Karya .

Mulyanti, P. (2013). (Doctoral dissertation, Fakultas Psikologi). BENTUKBENTUK DAN PENYEBAB KENAKALAN SISWA.

Mursidin. (2011). Profesionalisme Guru Menurut Al-Qur'an, Hadits dan Ahli Pendidikan Islam. Jakarta: Sedaun Anggota IKAPI.

Nazir, M. (2003). Metode Penelitian. Jakarta: Ghalia Indonesia.

Nizar, S. (2002). Filsafat Pendidikan Islam ; Pendekatan Historis, Teoritis dan Praktis. Jakarta: Ciputat Press.

Prabadewi, K., \& Widiasavtri, P. (2014). Hubungan konsep diri akademik dengan motivasi berprestasi pada remaja awal yang tinggal di panti asuhan di Denpasar. Jurnal Psikologi Udayana, 261-270.

Prasasti, S. (2017). Kenakalan remaja dan faktor penyebabnya . In Prosiding Seminar Nasional Bimbingan dan Konseling, 28-45.

Putra, N. (2013). Peranan komunikasi interpersonal orang tua dan anak dalam mencegah perilaku seks pranikah di SMA Neferi 3 Samarinda kelas XII. Ejournal Ilmu Komunikasi, 35-53.

Rahmawati, N. (2016). Kenakalan Remaja dan Kedisiplinan: Perspektif psikologi dan islam. Sawwa:. Jurnal Studi Gender , 267-268.

Rofiq, M. N. (2010). Pembelajaran kooperatif (cooperative learning) dalam pengajaran pendidikan agama Islam. Jurnal Falasaifa, 1-14.

Samsul, N. (2002). Filsafat Pendidikan Islam; Pendekatan Historis, Teoristis dan Praktis. Jakarta : Ciputat Press.

Sarwono. (2007). Psikologi Remaja. Jakarta: Raja Grafindo Persada.

Siyoto , S. M. (2015). Dasar Metodologi Penelitian . Yogyakarta: Literasi Media Publishing.

Soerjono, S. (2002). Sosiologi Suatu Pengantar. Jakarta: Rajawali Press.

Sugiyono. (2015). Metode Penelitian Kuantitatif, Kualitataif dan R\&D. Bandung: Alfabeta.

Sumara, D. H., \& Santoso, M. B. (2017). Kenakalan Remaja dan Penanganannya. Prosiding Penelitian dan Pengabdian Kepada Masyarakat. 